\title{
Article
}

\section{Investigating Undergraduate Science Students' Conceptions and Misconceptions of Ocean Acidification}

\author{
Kathryn I. Danielson and Kimberly D. Tanner \\ SEPAL: The Science Education Partnership and Assessment Laboratory, Department of Biology, San Francisco \\ State University, San Francisco, CA 94132
}

Submitted November 17, 2014; Revised May 27, 2015; Accepted May 27, 2015

Monitoring Editor: Michèle Shuster

\begin{abstract}
Scientific research exploring ocean acidification has grown significantly in past decades. However, little science education research has investigated the extent to which undergraduate science students understand this topic. Of all undergraduate students, one might predict science students to be best able to understand ocean acidification. What conceptions and misconceptions of ocean acidification do these students hold? How does their awareness and knowledge compare across disciplines? Undergraduate biology, chemistry/biochemistry, and environmental studies students, and science faculty for comparison, were assessed on their awareness and understanding. Results revealed low awareness and understanding of ocean acidification among students compared with faculty. Compared with biology or chemistry/biochemistry students, more environmental studies students demonstrated awareness of ocean acidification and identified the key role of carbon dioxide. Novel misconceptions were also identified. These findings raise the question of whether undergraduate science students are prepared to navigate socioenvironmental issues such as ocean acidification.
\end{abstract}

\section{INTRODUCTION}

Science education aims to equip students with knowledge and skills that will serve them in understanding the prominent issues of modern society. Scientific understanding of the basic concepts underlying genetically modified organisms, human health and disease, and global climate change could aid students in navigating these topics in their everyday lives. But to what extent do science students use conceptual ideas they have studied in their formal science education to explain environmental phenomena, such as climate change and its impact on the ocean, specifically ocean acidification?

CBE Life Sci Educ September 2, 2015 14:ar29

DOI:10.1187/cbe-14-11-0209

Address correspondence to: Kathryn I. Danielson (kdanielson2@ gmail.com).

(c) 2015 K. I. Danielson and K. D. Tanner. CBE-Life Sciences Education (c) 2015 The American Society for Cell Biology. This article is distributed by The American Society for Cell Biology under license from the author(s). It is available to the public under an Attribution-Noncommercial-Share Alike 3.0 Unported Creative Commons License (http://creativecommons.org/licenses/by-nc-sa/3.0).

"ASCB®" and" The American Society for Cell Biology ${ }^{\circledR}$ " are registered trademarks of The American Society for Cell Biology.
Recently, ocean acidification has come to the forefront of the global climate change discussion (Andersson and Mackenzie, 2011). Ocean acidification is referred to as "the other $\mathrm{CO}_{2}$ problem" of climate change, with global warming being the more widely discussed (Doney et al., 2009). Ocean acidification is the result of anthropogenic carbon pollution, in the form of the atmospheric greenhouse gas carbon dioxide $\left(\mathrm{CO}_{2}\right)$ being absorbed by the oceans, resulting in a subsequent drop in the water's pH (Fabry et al., 2008). In the past $200 \mathrm{yr}$, the oceans have absorbed approximately one-third of all atmospheric carbon dioxide, and the average ocean $\mathrm{pH}$ has dropped from 8.2 to $8.1 \mathrm{U}$ and is projected to drop $0.3-0.4$ U by 2100 (Sabine et al., 2004; Orr et al., 2005; Logan, 2010).

The scientific community considers it a priority to establish public awareness and understanding of ocean acidification (Logan, 2010; Andersson and Mackenzie, 2011). Several websites and summary documents are dedicated to addressing the public's questions about climate change and the scientific principles behind ocean acidification (National Geographic Society et al., 2005; U.S. Global Change Research Program, 2009; Fauville et al., 2012). Yet awareness of ocean acidification is known to be low among the general public. Research conducted by the Ocean Project revealed that awareness of ocean acidification was very low among adults 
in the United States, even among those who self-identified as concerned about climate change (Ocean Project, 2012).

Perhaps it is not surprising that the general public, especially those with little or no scientific training, would have low levels of awareness and understanding of ocean acidification. However, one might predict that those with an academic background in science, such as undergraduate science majors, would exhibit awareness and some conceptual understanding of ocean acidification. Undergraduate students from scientific disciplines such as biology, chemistry/biochemistry, and environmental studies experience a multidisciplinary science curriculum in which they likely encounter fundamental scientific concepts that could contribute to understanding environmental implications of climate change and ocean acidification. A scientific understanding of the $\mathrm{pH}$ scale, acid-base chemical reactions, and the molecular behavior of carbon dioxide in seawater would aid in students' conceptions of ocean acidification. The notion that science majors, in particular, would invoke basic ideas learned in their disciplines and apply them in novel situations appears to be either an aspiration or an assumption held by many undergraduate science instructors.

Previous research that has investigated students' understanding of climate change and its impact on the ocean has focused primarily on the physical impacts, such as ocean temperature changes due to global warming (Shepardson et al., 2011). Other studies have assessed $K-12$ students, preservice teachers, and undergraduate non-science majors' general conceptions of climate change, without attention to undergraduate science students (Boyes and Stainsstreet, 1992; Dove, 1996; Andersson and Wallin, 2000; Khalid, 2001; Lambert et al., 2012; Lombardi and Sinatra, 2012; Howard et al., 2013). Some studies (e.g., Wilson et al., 2006; Hartley et al., 2011) have investigated the extent to which undergraduate science students understand concepts related to the carbon cycle, which are relevant to issues of climate change and ocean acidification. Findings from these studies suggest that undergraduate science students struggle to consistently apply scientific principles such as conservation of matter and energy to new contexts, particularly when problems require students to trace matter and energy across successive scales of biological organization.

Investigating undergraduate students' conceptions and misconceptions of ocean acidification offers a chance to understand how a group of future scientific leaders think about science in the context of a real-world phenomenon that is of increasing importance in global climate change, ocean acidification. Our study addressed three questions: 1) How do advanced undergraduate science students, that is, juniors and seniors in the disciplines of biology, chemistry/ biochemistry, and environmental studies, explain the impact of climate change on the oceans, specifically ocean acidification? 2) What conceptions and misconceptions of ocean acidification do these students hold, and how do these students' ideas compare with those of other students and faculty from the same scientific disciplines? 3) How do students perceive their undergraduate science education contributing to their understanding of climate change?

\section{METHODS}

Qualitative and quantitative data were collected via purposeful sampling of undergraduate science students and science faculty at a large (more than 25,000 undergraduate students), public university in the United States (Table 1). Written assessment data were collected using a novel written assessment tool (Box 1). Post hoc, quantitative and comparative statistical analyses were performed to detect significance of trends among the participant populations.

\section{Participant Populations}

Undergraduate science students of junior- or senior-class standing who were majoring in biology, chemistry/biochemistry, or environmental studies were recruited. These student disciplines were selected because of their direct connections to the topics of climate change, greenhouse gases, and ocean acidification. To generate an expert data set for comparison with students' conceptions, we recruited faculty from the biology, chemistry/biochemistry, environmental studies, and geosciences departments at the same university.

\section{Written Assessment}

To our knowledge, no validated tool designed to assess undergraduate science students' understanding of ocean acidification exists. Thus, we developed a novel written assessment tool (Box 1) consisting of a series of six assessment items written as "challenge statements," which prompted participants to respond first to a question with a closed-ended answer scale and then to supply an open-ended written response explaining their reasoning.

Assessment items followed a specific order. Items 1-4 addressed specific science content knowledge on climate change, greenhouse gases, and ocean acidification, and

Table 1. Participant population ${ }^{\mathrm{a}}$

\begin{tabular}{lccccc}
\hline & & \multicolumn{3}{c}{ Academic discipline } \\
\cline { 3 - 6 } \multicolumn{1}{c}{ Population } & $n$ & Biology & $\begin{array}{c}\text { Chemistry/ } \\
\text { biochemistry }\end{array}$ & $\begin{array}{c}\text { Environmental } \\
\text { studies }\end{array}$ & Geosciences \\
\hline $\begin{array}{l}\text { Science faculty } \\
\text { Undergraduate science }\end{array}$ & 12 & 4 & 3 & 2 & 3 \\
students $^{\mathrm{c}}$ & 246 & 134 & 60 & 52 & - \\
\hline
\end{tabular}

${ }^{\mathrm{a}}$ Values represent the participant populations for the written assessment.

${ }^{b}$ Tenured or tenure-track faculty with primary research or educational interest in climate change were recruited to participate in this study. ${ }^{c}$ Undergraduate students of junior- or senior-class standing in the disciplines of biology, chemistry/biochemistry, or environmental studies were recruited to participate in this study. 
or non-science majors or did not complete the assessment. Twenty percent of the students were of junior-class standing, and $80 \%$ were of senior-class standing. Participant demographics resembled the institutional profile; $40 \%$ male, $60 \%$ female, 28\% white, 28\% Asian, 13\% Latino/a, 12\% Filipino, $9 \%$ other, $5 \%$ declined to state, and $4 \%$ African American. Of the 17 faculty who were invited to participate, 12 completed the written assessment ( $71 \%$ participation rate).

\section{Assessment Item 1: "Climate Change Impacts the Ocean"}

Item 1 aimed to quantify the specific impacts of climate change on the ocean cited by participants in response to a broad statement. Figure 1A shows that most faculty $(92 \%, n=11 / 12)$ and students selected "agree" on the closed-ended scale for this assessment item $(\chi=1.279, p=0.5275)$. Similar proportions of biology $(95 \%, n=127 / 134)$, chemistry / biochemistry $(98 \%, n=$ $59 / 60)$, and environmental studies $(96 \%, n=50 / 52)$ selected "agree" as well (Figure 1A, $\chi=3.048, p=0.5499$ ).

Analyses of written responses investigated the specific climate change impacts participants listed and whether they mentioned ocean acidification without prompting. Four main categories of impacts emerged from participants' responses: changes in atmospheric and ocean temperatures (Figure 1B), melting ice (Figure 1C), sea level rise (Figure 1D), and ocean acidification (Figure 1E). Table 2 shows representative quotes reflecting these four main categories.

In their written responses, a significantly greater proportion of faculty $(100 \%, n=12 / 12)$ listed changes in ocean and atmospheric temperatures, such as global warming and ocean warming, compared with all students (Figure 1B, $\chi=4.686, p=0.0304^{*},{ }^{*} p<0.01$ ). Of the three student populations, a greater proportion of environmental studies students $(81 \%, n=42 / 52)$ listed changes in ocean and atmospheric temperatures, compared with biology $(73 \%, n=98 / 134)$ and chemistry/biochemistry $(60 \%, n=36 / 60)$ students (Figure 1B, $\chi=6.268, p=0.0435^{*}$ ).

There was no significant difference between the proportion of faculty $(67 \%, n=8 / 12)$ who listed the impact of melting ice, in the form of glaciers and polar ice caps, compared with all students (Figure $1 C, \chi=2.308, p=0.1287$ ). Similar proportions of biology $(44 \%, n=59 / 134)$, chemistry/biochemistry $(43 \%, n=26 / 60)$, and environmental studies $(46 \%$, $n=24 / 52)$ students listed the impact of melting ice (Figure 1C, $\chi=0.099, p=0.9517)$.

There was also no significant difference between the proportion of faculty $(50 \%, n=6 / 12)$ who listed the impact of sea level rise, compared with all students (Figure 1D, $\chi=$ $0.222, p=0.6372$ ). Of the three student populations, a greater proportion of environmental studies students $(54 \%, n=$ $28 / 52$ ) listed the impact of sea level rise, compared with $37 \%$ of biology $(n=49 / 134)$ and $48 \%$ of chemistry/biochemistry $(n=29 / 60)$ students (Figure 1D, $\chi=5.451, p=0.0655)$.

However, there were significant differences between populations that listed ocean acidification in their written responses to this item. Figure $1 \mathrm{E}$ shows that a significantly greater proportion of faculty $(n=7 / 12)$ listed the impact ocean acidification, compared with all students, although it was only $58 \%$ of faculty $\left(\chi=14.093, p<0.0002^{*}\right)$. Of the three student populations, a greater proportion of environmental studies students $(37 \%, n=19 / 52)$ listed ocean acidification, compared with only $12 \%$ of biology $(n=16 / 134)$ and $7 \%$ of chemistry/biochemistry $(n=4 / 60)$ students (Figure $1 \mathrm{E}$, $\chi=22.012, p<0.0001^{*}$ ).

\section{Assessment Item 2: "The Main Impact Greenhouse Gases Have on the Ocean Is They Increase the Ocean's Temperature"}

The goal of item 2 was to prompt participants to think about other impacts of greenhouse gases on the ocean, such as ocean acidification. We predicted that if participants disagreed on the closed-ended scale for this item, they would cite ocean acidification as the main impact of greenhouse gases on the ocean.

Figure 2A shows that a greater proportion of faculty ( $42 \%$, $n=5 / 12)$ selected "disagree" on the closed-ended scale for this item, compared with all students $(\chi=4.427, p=0.1093)$. There were significant differences among the student populations' closed-ended responses; a greater proportion of environmental studies students $(36 \%, n=19 / 52)$ selected "disagree," compared with biology (20\% $n=27 / 134)$ and chemistry/biochemistry $(20 \%, n=12 / 60)$ students (Figure 2A, $\chi=13.861, p=0.0078^{*}$ ).

Analyses of written responses investigated whether participants cited ocean acidification as the main impact of greenhouse gases on the ocean, as opposed to increasing temperatures. The same four categories of impacts from the assessment item 1 responses emerged in item 2 responses, and in similar proportions. However, while they did not generally disagree on the closed-ended scale, a significantly greater proportion of faculty $(92 \%, n=11 / 12)$ did list ocean acidification as the main impact of greenhouse gases on the ocean, compared with all students (Figure 2B, $\left.\chi=39.004, p<0.0001^{*}\right)$. Of the three student populations, $\mathrm{a}$ greater proportion of environmental studies students $(31 \%$, $n=16 / 52$ ) listed ocean acidification as the main impact of greenhouse gases on the ocean, compared with only $15 \%$ of biology $(n=20 / 134)$ and $10 \%$ of chemistry/biochemistry $(n=6 / 60)$ students (Figure $\left.2 \mathrm{~B}, \chi=9.446, p=0.0089^{*}\right)$.

\section{Assessment Item 3: "Before Today, Had You Heard of Greenhouse Gases? Please Describe What You Think Greenhouse Gases Are"}

Item 3 explicitly probed participants' awareness and conceptions of greenhouse gases, to distinguish between participants who had prior knowledge of greenhouse gases and carbon dioxide $\left(\mathrm{CO}_{2}\right)$, but who perhaps did not discuss these in their responses to items 1 and 2, and participants who lacked the conceptual knowledge of these topics altogether.

Figure $3 \mathrm{~A}$ shows that $100 \%$ of faculty $(n=12 / 12)$, and most students, selected "yes" on the closed-ended scale for this item $(\chi=0.507, p=0.4762)$. Of the three student populations, $94 \%$ of biology $(n=126 / 134), 97 \%$ of chemistry/ biochemistry $(n=58 / 60)$, and $100 \%$ of environmental studies $(n=52 / 52)$ students selected "yes" on the closed-ended scale for this assessment item (Figure 3A, $\chi=3.533, p=0.1709$ ).

Analyses of written responses investigated whether participants listed correct examples of greenhouse gases, and specifically whether they named carbon dioxide. Figure 3B shows that $83 \%$ of faculty $(n=10 / 12)$ correctly named one or more example(s) of a greenhouse gas, such as carbon dioxide $\left(\mathrm{CO}_{2}\right)$, 
A. Closed-ended scale

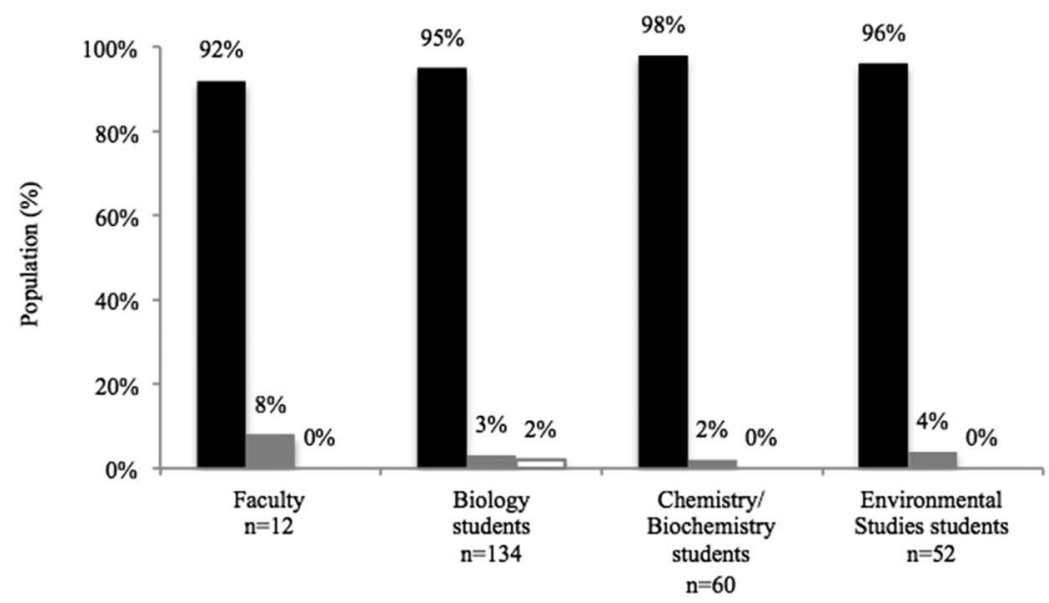

B. Changes in atmospheric and ocean temperatures

C. Melting ice
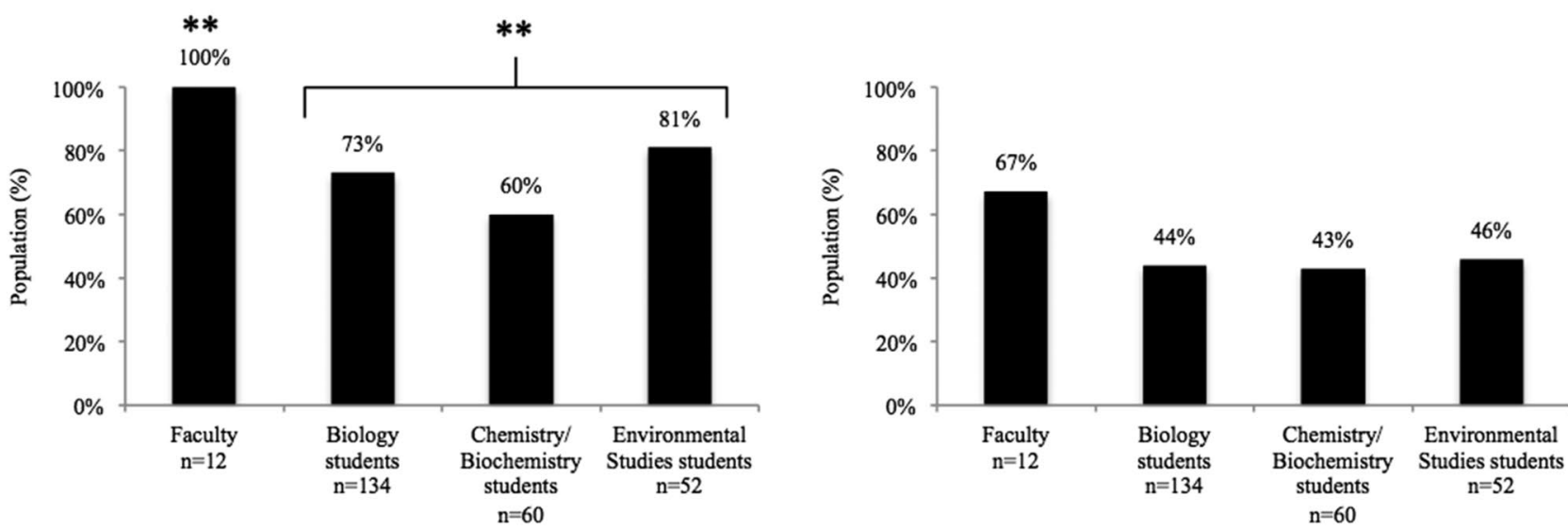

D. Sea level rise

E. Ocean acidification
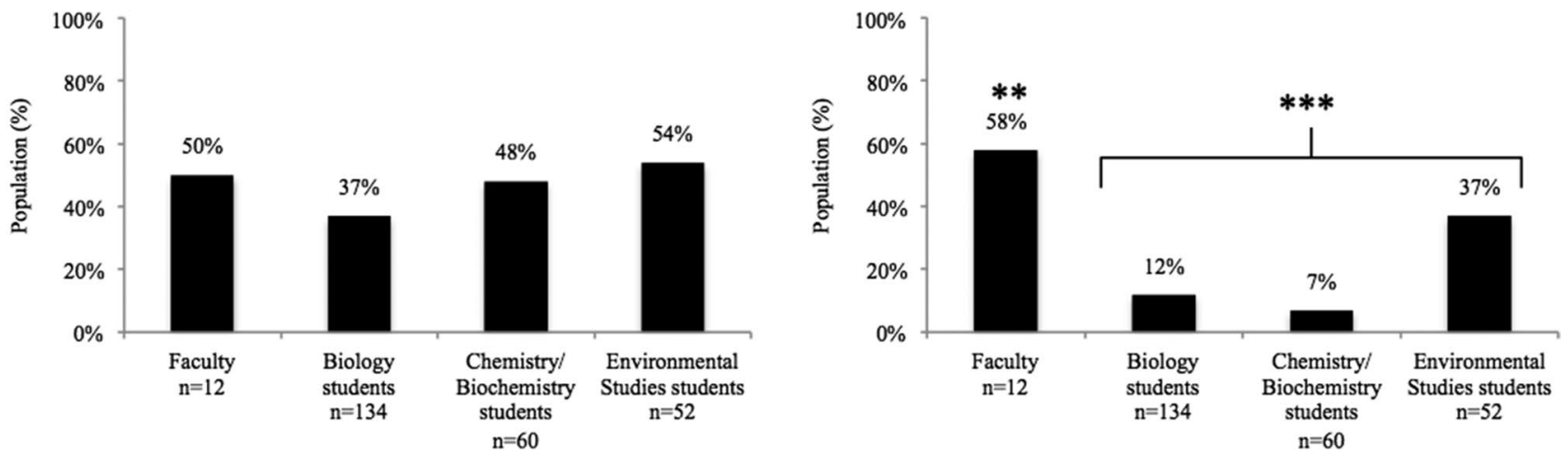

Figure 1. Participants' responses to assessment item 1: "Climate change impacts the ocean." (A) Closed-ended scale: "agree" (black), "disagree" (gray), and "don't know" (white). The four main categories of climate change impacts cited in participants' open-ended written responses were: (B) changes in ocean and atmospheric and ocean temperatures ${ }^{* *}, p<0.01$ : faculty compared with all students; ${ }^{* *}, p<0.01$ : among biology, chemistry/biochemistry, and environmental studies students), (C) melting ice, (D) sea level rise, and (E) ocean acidification $\left({ }^{* *}, p<0.01\right.$ : faculty compared with all students; ${ }^{* * *}, p<0.0001$ : among biology, chemistry /biochemistry, and environmental studies students). 
Table 2. The four main categories of impacts that emerged from participants' written responses to the assessment item "Climate change impacts the ocean"a

\begin{tabular}{|c|c|c|c|c|}
\hline \multirow[b]{2}{*}{ Population } & \multicolumn{4}{|c|}{ Impact } \\
\hline & $\begin{array}{l}\text { Changes in atmospheric } \\
\text { and ocean temperatures }\end{array}$ & Melting ice & Sea level rise & Ocean acidification \\
\hline $\begin{array}{l}\text { Science faculty, } \\
\quad n=12\end{array}$ & $\begin{array}{l}\text { "Long-wave infrared } \\
\text { radiation increases } \\
\text { as greenhouse gas } \\
\text { concentrations increase } \\
\text { and the atmosphere } \\
\text { warms, thereby warm- } \\
\text { ing the ocean surface." }\end{array}$ & $\begin{array}{l}\text { "[There is] melting of } \\
\text { polar ice caps and } \\
\text { glaciers." }\end{array}$ & $\begin{array}{l}\text { "Sea level rise and water } \\
\text { expansion will flood } \\
\text { low-lying coastal } \\
\text { areas." }\end{array}$ & $\begin{array}{l}\text { "CO } \mathrm{CO}_{2} \text { can impact the ocean in a } \\
\text { number of ways. Directly, by } \\
\text { dissolving in the ocean and } \\
\text { causing ocean acidification } \\
\text { and ocean carbonate issues." }\end{array}$ \\
\hline $\begin{array}{l}\text { Biology students, } \\
\quad n=134\end{array}$ & $\begin{array}{l}\text { "Climate change affects } \\
\text { the temperature of } \\
\text { the ocean's water. } \\
\text { Some organisms can } \\
\text { only live in certain } \\
\text { temperatures so they } \\
\text { might die." }\end{array}$ & $\begin{array}{l}\text { "Melting of the ice caps } \\
\text { happens too. Polar } \\
\text { bears are loosing [sic] } \\
\text { habitats and prime } \\
\text { hunting spaces." }\end{array}$ & $\begin{array}{l}\text { "Climate change has a } \\
\text { huge impact on the } \\
\text { ocean because of the } \\
\text { sea level rising." }\end{array}$ & $\begin{array}{l}\text { "The } \mathrm{pH} \text { of the ocean is slowly } \\
\text { becoming more acidic due to } \\
\text { the absorption of } \mathrm{CO}_{2} \text {, which } \\
\text { will eventually effect creatures } \\
\text { who use the bicarbonate in } \\
\text { the ocean to make their shells, } \\
\text { and may ultimately impact the } \\
\text { feeding cycles in all marine } \\
\text { animals." }\end{array}$ \\
\hline $\begin{array}{l}\text { Chemistry/ } \\
\text { biochemistry } \\
\text { students, } n=60\end{array}$ & $\begin{array}{l}\text { "When I think of climate } \\
\text { change, I think of a } \\
\text { change in temperature } \\
\text { in a certain region, } \\
\text { and this can impact } \\
\text { the ocean primarily by } \\
\text { the temperature of the } \\
\text { sea." }\end{array}$ & $\begin{array}{l}\text { "Climate change can } \\
\text { cause the ice caps in } \\
\text { both of the Earths' } \\
\text { poles to melt." }\end{array}$ & $\begin{array}{l}\text { "Climate change causes } \\
\text { the sea level to rise." }\end{array}$ & $\begin{array}{l}\text { "Climate change is increasing } \\
\text { oceanic acidity, preventing } \\
\text { coral from growing correctly." }\end{array}$ \\
\hline $\begin{array}{l}\text { Environmental } \\
\quad \text { studies students, } \\
n=52\end{array}$ & $\begin{array}{l}\text { "Climate change impacts } \\
\text { the ocean [by] an } \\
\text { increase in the global } \\
\text { temperature, which } \\
\text { will cause the ocean's } \\
\text { temperature to rise." }\end{array}$ & $\begin{array}{l}\text { "Climate change impacts } \\
\text { the ocean in various } \\
\text { ways [such as] how } \\
\text { fast many glaciers are } \\
\text { melting every year." }\end{array}$ & $\begin{array}{l}\text { "Climate change impacts } \\
\text { ocean levels, i.e., sea } \\
\text { level rise." }\end{array}$ & $\begin{array}{l}\text { "The ocean acts as a sink for } \mathrm{CO}_{2} \\
\text { and other greenhouse gases. As } \\
\text { the ocean absorbs more } \mathrm{CO}_{2} \text { the } \\
\text { ocean becomes more acidic." }\end{array}$ \\
\hline
\end{tabular}

${ }^{\text {a}}$ Quotes come from participants' open-ended written responses to assessment item 1 . Written responses usually included multiple impacts.

methane $\left(\mathrm{CH}_{4}\right)$, or water vapor $\left(\mathrm{H}_{2} \mathrm{O}\right)$, compared with all students $(\chi=2.670, p=0.1023)$. Of the three student populations, a greater proportion of environmental studies students $(81 \%$, $n=42 / 52)$ correctly named one or more example(s) of a greenhouse gas, compared with only $53 \%$ of biology $(n=71 / 134)$ or $57 \%$ chemistry / biochemistry $(n=34 / 60)$ students (Figure 3B, $\left.\chi=12.341, p=0.0021^{*}\right)$. Only $7 \%$ of all students $(n=17 / 246)$ listed one or more incorrect example of greenhouse gases, such as "nitrogen gas, oxygen, carbon binoxide," compared with $0 \%$ of faculty $(n=0 / 12 ; \chi=1.173, p=0.7594)$.

Figure $3 \mathrm{C}$ shows that a significantly greater proportion of faculty $(83 \%, n=10 / 12)$ specifically named carbon dioxide as a greenhouse gas, compared with all students $(\chi=3.967, p=$ $\left.0.0464^{*}\right)$. Of the three student populations, a greater proportion of environmental studies students $(81 \%, n=42 / 52)$ specifically named carbon dioxide as a greenhouse gas, compared with biology $(44 \%, n=59 / 134)$ and chemistry/biochemistry $(53 \%, n=32 / 60)$ students (Figure 3C, $\left.\chi=20.378, p<0.0001^{*}\right)$.

\section{Assessment Item 4: "Have You Heard of Ocean Acidification? Please Describe What You Think Ocean Acidification Is"}

Item 4 explicitly probed participants' awareness and conceptions of ocean acidification and was the final assessment item that addressed specific science content knowledge. It aimed to distinguish between participants who had prior knowledge of ocean acidification, but did not discuss it in their responses to items 1 and 2, and participants who lacked the conceptual knowledge of this topic altogether. Table 3 shows representative quotes from written responses to assessment item 4 .

A significantly greater proportion of faculty $(100 \%, n=$ $12 / 12)$ selected "yes" on the closed-ended scale for this item, compared with all students (Figure 4A, $\chi=12.392$, $\left.p<0.0004^{*}\right)$. Of the three student populations, a greater proportion of environmental studies students $(92 \%, n=48 / 52)$ selected "yes" on the closed-ended scale, compared with biology (42\%, $n=56 / 134)$ and chemistry/biochemistry $(23 \%, n=14 / 60)$ students (Figure 4A, $\chi=57.598, p<0.0001^{*}$ ).

Analyses of written responses investigated whether participants used a scientifically accurate explanation for the cause of ocean acidification. One hundred percent of faculty ( $n=12 / 12)$ used a scientifically accurate explanation of ocean acidification, explaining that the dissolution of anthropogenic atmospheric carbon dioxide caused ocean acidification, compared with all students (Figure 4B, $\chi=31.894, p<0.0001^{*}$ ). Of the three student populations, a greater proportion of environmental studies students $(48 \%, n=25 / 52)$ used carbon dioxide to explain the cause of ocean acidification, compared 
A. Closed-ended scale

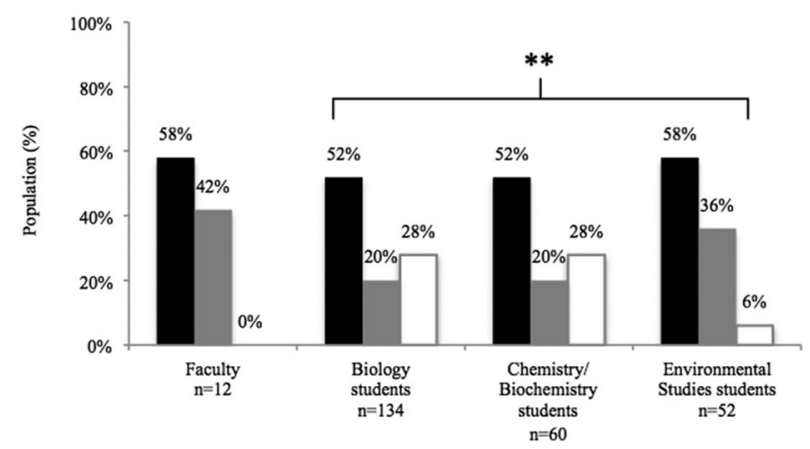

B. Ocean acidification

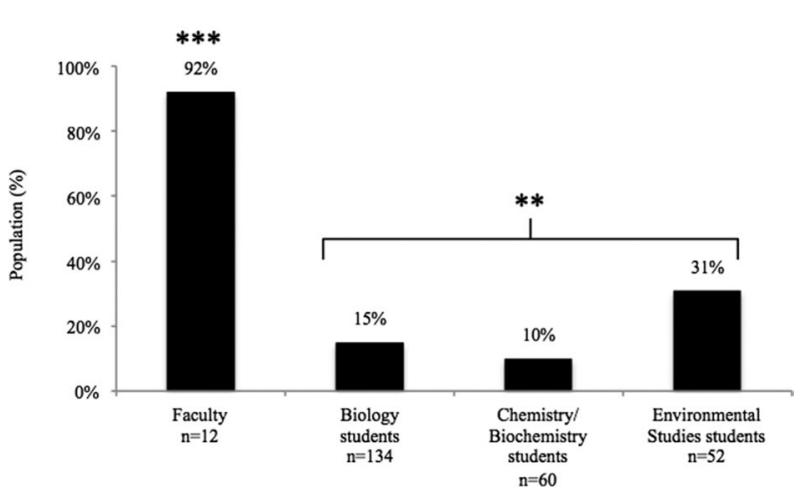

Figure 2. Participants' responses to assessment item 2: "The main impact greenhouse gases have on the ocean is they increase the ocean's temperature." (A) Closed-ended scale: "agree" (black), "disagree" (gray), and "don't know" (white; **, $p<0.01$ : among biology, chemistry/biochemistry, and environmental studies students). (B) Participants who listed ocean acidification as the main impact of greenhouse gases on the ocean in their open-ended written responses $\left(* * *, p<0.0001\right.$ : faculty compared with all students; ${ }^{* *}, p<0.01$ : among biology, chemistry/biochemistry, and environmental studies students).

with less than a quarter of biology $(21 \%, n=28 / 134)$ and chemistry / biochemistry $(13 \%, n=8 / 60)$ students (Figure $4 \mathrm{~B}$, $\left.\chi=20.435, p<0.0001^{*}\right)$.

Further, multiple novel student misconceptions about the cause of ocean acidification were revealed without prompting. A significantly greater proportion of students used a misconception to explain ocean acidification, compared with $0 \%$ of faculty $\left(n=0 / 12\right.$; Figure 4 C, $\left.\chi=3.897, p=0.0484^{*}\right)$. Specifically, $28 \%$ of biology $(n=38 / 134), 22 \%$ of chemistry/ biochemistry $(n=13 / 60)$, and $19 \%$ of environmental studies students $(n=10 / 52)$ explained that acid rain and/or chemical pollution, such as toxic waste from industry, caused ocean acidification (Figure $4 C, \chi=2.091, p=0.3516$ ).

\section{Assessment Item 5: "The Big Ideas I Have Studied as Part of My Scientific Discipline Are Necessary for Me to Understand Climate Change"}

Item 5 assessed the extent to which students and faculty thought the big ideas or governing principles of their
A. Closed-ended scale



B. Correctly named $\geq 1$ example(s)

of a greenhouse gas

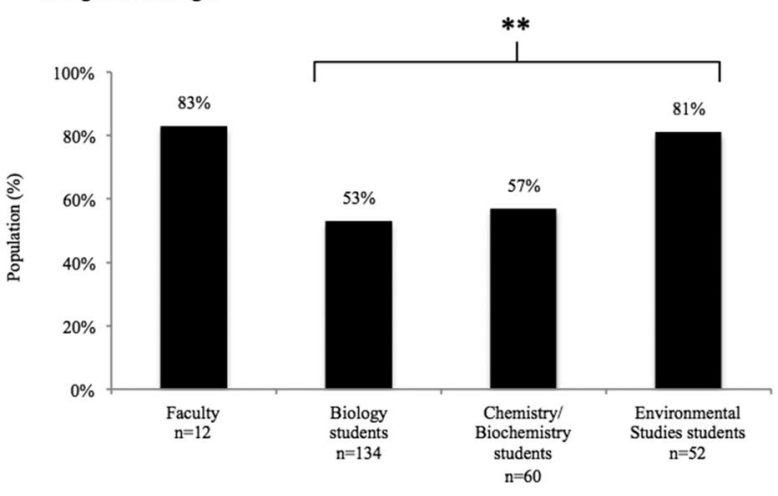

C. Named $\mathrm{CO}_{2}$ as example of a greenhouse gas

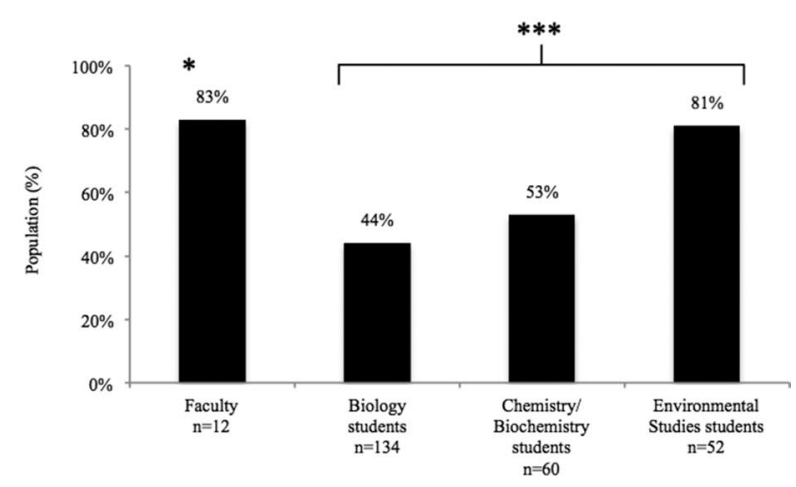

Figure 3. Participants' responses to assessment item 3: "Before today, had you heard of greenhouse gases? Please describe what you think greenhouse gases are." (A) Closed-ended scale: "yes" (black) or "no" (gray). (B) Participants who correctly named more than one example of a greenhouse gas in their open-ended written responses $\left({ }^{* *}, p<0.01\right.$ : among biology, chemistry/biochemistry, and environmental studies students). (C) Participants who specifically named carbon dioxide as a greenhouse gas in their open-ended written responses $\left({ }^{*}, p<0.05\right.$ : faculty compared with all students; ${ }^{* *}, p<0.0001$ : among biology, chemistry/biochemistry, and environmental studies students).

scientific disciplines were relevant to understanding climate change. Most faculty $(92 \%, n=11 / 12)$ selected "agree" on the closed-ended scale for this item, compared with all students (Figure $5, \chi=1.880, p=0.3906$ ). However, of the three student populations, a greater proportion of biology (28\%, $n=37 / 134)$ and chemistry/biochemistry 
Table 3. Undergraduate science students' conceptions and misconceptions of ocean acidification from written responses to the assessment item "Have you heard of ocean acidification? Please describe what you think ocean acidification is"a

\section{Scientifically accurate conceptions \\ Dissolution of anthropogenic $\mathrm{CO}_{2}$ from the atmosphere causes ocean acidification}

\section{Misconceptions}

Chemical pollution causes ocean acidification

Acid rain causes ocean acidification
"[Ocean acidification] is from the ocean becoming more acidic from being a sort of sink into which gases become trapped, such as $\mathrm{CO}_{2}$, and causing the $\mathrm{pH}$ to be lowered." -Biology student

"[Ocean acidification] is the lowering of ocean $\mathrm{pH}$ due to increased levels of $\mathrm{CO}_{2}$ in the atmosphere, resulting in more dissolved $\mathrm{CO}_{2}$ in the ocean." - Chemistry / biochemistry student

"Ocean acidification is the change in $\mathrm{pH}$ that happens with increased levels of $\mathrm{CO}_{2}$ in the atmosphere. $\mathrm{CO}_{2}$ in the atmosphere dissolves readily in water, forming carbonic acid, lowering the overall $\mathrm{pH}$ of the ocean, creating a more acidic ocean." -Environmental studies student

"Ocean acidification ... is the exposure of toxic chemicals into the ocean. This acidification is caused by the careless usage of chemicals and the irresponsible disposal of them." -Biology student

"Ocean acidification refers to when the waste from many factories is dumped into the ocean. The waste includes many toxic chemicals." - Chemistry/biochemistry student

"When pesticides or nutrients from agriculture or pollutants from industrial processes enter an oceanic environment, lowering of the $\mathrm{pH}$ can occur." -Environmental studies student

"Ocean acidification refers to the change in the $\mathrm{pH}$ in the oceans due to acid rain." -Biology student

"When acid rain showers over the ocean, the ocean gets contaminated with acid and gives rise to ocean acidification." - Chemistry/biochemistry student

"Ocean acidification is caused by acid rain. Acid rain is caused by too much $\mathrm{SO}_{2}$ gas in the atmosphere. The $\mathrm{SO}_{2}$ gas from burning coal goes into the atmosphere and reacts with $\mathrm{H}_{2} \mathrm{O}$. When this falls down as rain, it causes ocean acidification." -Environmental studies student

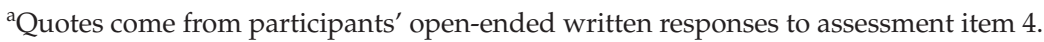

(30\%, $n=18 / 60)$ students selected "disagree" on the closed-ended scale for this item, compared with environmental studies students $(11 \%, n=6 / 52$; Figure $5, \chi=7.104$, $p=0.1305)$. Those students who disagreed explained that they felt a background in science was not necessary to understand climate change ("I do not believe you need to have a background in science in order to understand climate change at all.") or that climate change did not directly relate to their scientific discipline ("As a [microbiology] major, I studied concepts that are very small in scale. So [...] I don't feel my studies are necessary to understand climate change.").

\section{Assessment Item 6: "Undergraduate Science Students Should Graduate with an Understanding of the Scientific Principles behind Climate Change"}

Item 6 explored whether students and faculty considered it important for students to graduate with an understanding of the scientific principles behind climate change. One hundred percent of faculty $(n=12 / 12)$, and a large proportion of students, selected "agree" on the closed-ended scale for this item (Figure 6, $\chi=1.910, p=0.3848$ ). One faculty member explained in his/her written response, "Science students are in the best position to understand the issue at the fundamental level and should take a leadership role in this regard." Of the three student populations, $88 \%$ of biology $(n=118 / 134)$, $78 \%$ of chemistry/biochemistry $(n=47 / 60)$, and $90 \%$ of environmental studies $(n=47 / 52)$ students selected "agree" (Figure 6, $\chi=8.459, p=0.0761$ ).

\section{DISCUSSION}

This research investigated undergraduate science students' awareness of ocean acidification, conceptions and misconceptions about ocean acidification, and perceptions of the role of their undergraduate science education in their awareness and understanding, all in comparison with findings from science faculty drawn from their disciplines. Here, we present four main findings, along with conclusions and future directions for deeper investigations into students' conceptions and misconceptions of ocean acidification.

\section{There Is Little Evidence to Support the Assumption That Undergraduate Science Students Understand Climate Change, Even Though Students and Faculty Agreed This Was an Important Outcome of Undergraduate Science Education}

Results indicated that students and faculty are in agreement that an understanding of the scientific principles behind climate change should result from an undergraduate science education (Figure 6). Students and faculty also agreed that big ideas from the scientific disciplines of biology, chemistry/biochemistry, and environmental studies are necessary for undergraduate science students to understand climate change (Figure 5). However, few students demonstrated scientifically accurate conceptions of climate change, specifically ocean acidification. These findings raise the question of whether undergraduate science students are prepared to navigate socioenvironmental issues related to their disciplines, such as 
A. Closed-ended scale

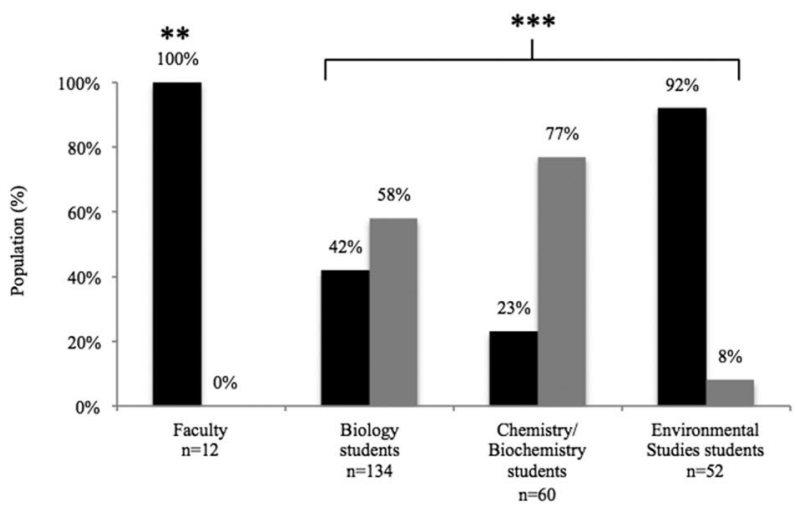

B. Used $\mathrm{CO}_{2}$ to explain the cause of ocean acidification

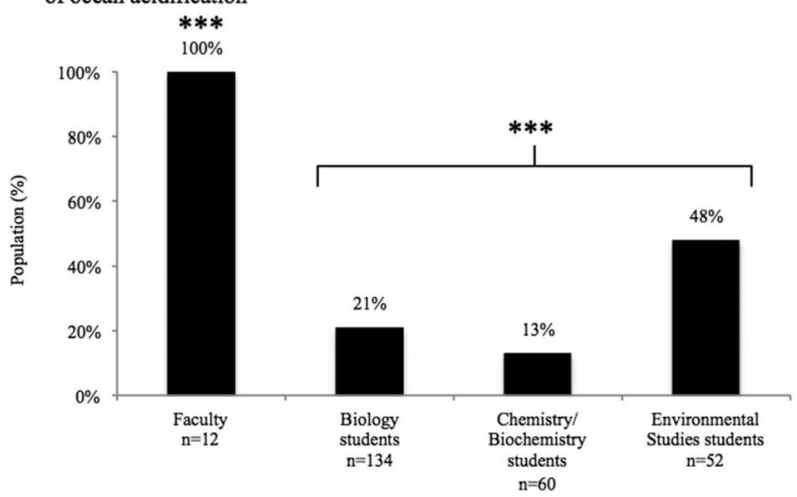

C. Used the misconception of acid rain and/or chemical pollution to explain the cause of ocean acidification

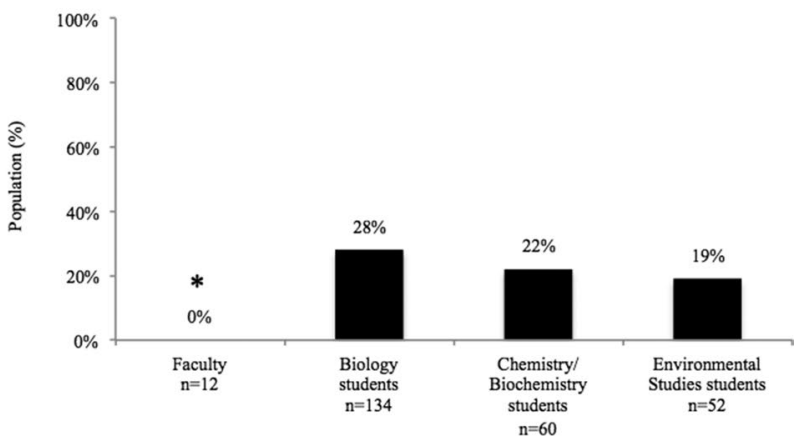

Figure 4. Participants' responses to assessment item 4: "Have you heard of ocean acidification? Please describe what you think ocean acidification is." (A) Closed-ended scale: "yes" (black) or "no" (gray; ${ }^{* *}, p<$ 0.01: faculty compared with all students; ${ }^{* * *}, p<0.0001$ : among biology, chemistry / biochemistry, and environmental studies students). (B) Participants who used carbon dioxide to explain the cause of ocean acidification in their open-ended written responses $(* *, p<0.0001$ : faculty compared with all students; ${ }^{* * *}, p<0.0001$ : among biology, chemistry/ biochemistry, and environmental studies students). (C) Participants who used the misconception of acid rain and/or chemical pollution to explain the cause of ocean acidification in their open-ended written responses $\left({ }^{*}, p<0.05\right.$ : faculty compared with all students).

ocean acidification. This is similar to previous research that revealed how undergraduate science students struggle to apply scientific principles from their disciplines in new contexts and at different organizational levels in living systems (Wilson et al., 2006; Hartley et al., 2011).

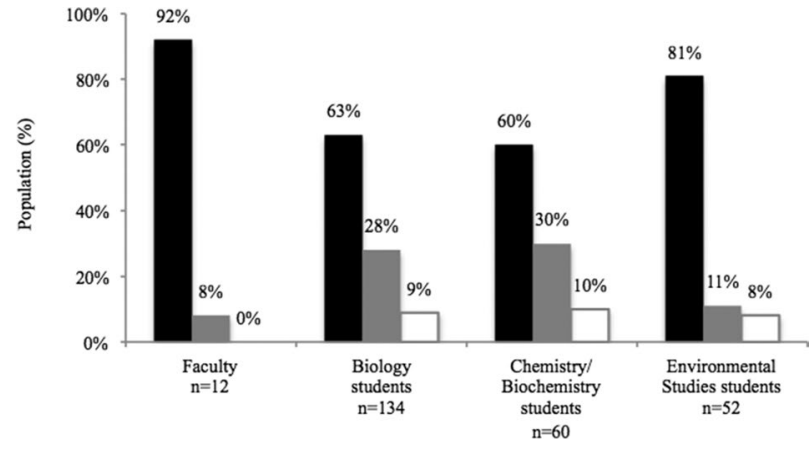

Figure 5. Participants' responses to assessment item 5: "The big ideas I have studied as part of my scientific discipline are necessary for me to understand climate change." Closed-ended scale: "agree" (black), "disagree" (gray), and "don't know" (white). Note that the faculty prompt was "The big ideas from my scientific discipline are necessary for undergraduate students to understand climate change."

\section{While Students Demonstrated Some Basic Knowledge of Climate Change and Greenhouse Gases, the Impact of Ocean Acidification Was Not Emphasized}

Our findings suggest that students, and perhaps some faculty, are more attuned to the temperature-related impacts of climate change on the ocean, compared with ocean acidification. More than $90 \%$ of students agreed with assessment item 1, "Climate change impacts the ocean" (Figure 1A). However, less than half of each student population, and only a slim majority of faculty, listed ocean acidification as an impact of climate change in their written responses to this assessment item (Figure 1E). Instead, the most prevalent climate change impact cited by both faculty and students was changes in atmospheric and ocean temperatures, such as global warming or increased sea surface temperatures (Figure 1B). Further, a majority of each participant population agreed with assessment item 2, "The main impact greenhouse gases have on the ocean is they increase the ocean's temperature" (Figure 2A).

Previous research supports this finding that students, and perhaps faculty, are most familiar with the temperature-related impacts of climate change on the ocean (Shepardson et al., 2012). This might be because students, and perhaps some faculty, do not consider ocean acidification to be an impact of climate change and instead consider it to be a

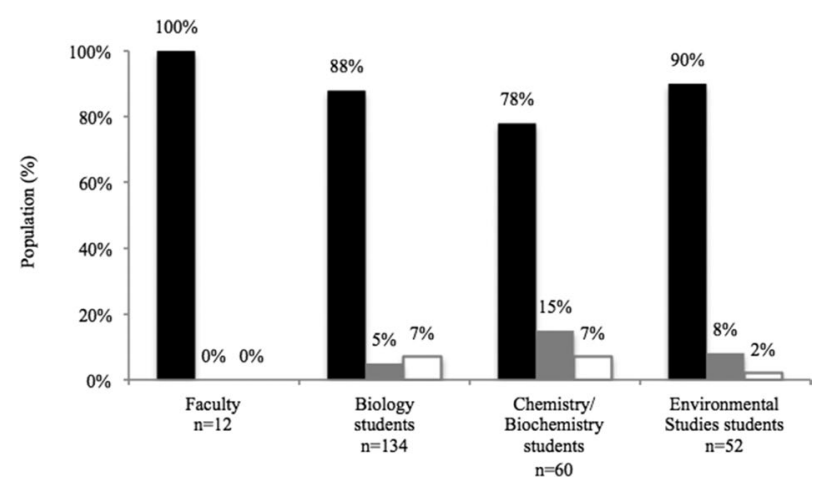

Figure 6. Participants' responses to assessment item 6: “Undergraduate science students should graduate with an understanding of the scientific principles behind climate change." Closed-ended scale: "agree" (black), "disagree" (gray), and "don't know" (white). 
separate phenomenon. Alternatively, this may simply be because ocean acidification is a new, but exponentially growing, topic of scientific research (Kroeker et al., 2013). Only a decade ago, temperature changes were the most common abiotic variable discussed in the majority of climate change-related marine ecology publications (Harley et al., 2006; Parmesan, 2006).

So why do undergraduate science students fail to reference ocean acidification in the context of climate change? Is it because students lack the conceptual knowledge needed to understand ocean acidification and are unfamiliar with greenhouse gases like carbon dioxide? Our results suggest this is not the case. On written assessments, more than $90 \%$ of students reported they had heard of greenhouse gases (Figure 3A), and without prompting, students from each discipline specifically named carbon dioxide as an example of a greenhouse gas (Figure 3C). However, fewer students appeared to connect their knowledge of carbon dioxide to ocean acidification. Only $21 \%$ of biology students, $13 \%$ of chemistry/biochemistry, and less than half of environmental studies students $(48 \%)$ used carbon dioxide to explain the cause of ocean acidification (Figure 4B). One might expect that if students could identify carbon dioxide as a greenhouse gas, a similar proportion might use this knowledge in the context of their explanations of ocean acidification.

\section{Multiple Novel Misconceptions about the Cause of Ocean Acidification Were Discovered among Each Student Population}

Misconceptions about the cause of ocean acidification were revealed in students' written assessment responses (Figure $4 \mathrm{C}$ and Table 3). Without prompting and in relatively equal proportions, biology, chemistry/biochemistry, and environmental studies students explained that acid rain and/or chemical pollution, such as toxic waste from industry or agricultural runoff, caused ocean acidification. Because we did not explicitly prompt participants to consider a relationship between acid rain or chemical pollution and ocean acidification, the prevalence of these ideas among students may be more extensive than we have reported here. Future studies could directly probe students with the statement "Acid rain and chemical pollution cause ocean acidification" to obtain a more accurate estimate of the proportion of undergraduate science students who may hold these ideas.

Students' understanding of climate change and a variety of environmental processes have been the subject of increasing study for the field of science education research, and some research has explored conceptions and misconceptions about acid rain, greenhouse gases, and the greenhouse effect. A study with preservice $\mathrm{K}-12$ teachers explored misconceptions surrounding greenhouse gases, carbon dioxide, and acid rain (Khalid, 2001). When responding to the statement "Acid rain is caused by the increase in greenhouse effect," most teachers' explanations cited carbon dioxide and chemical pollution in the atmosphere as causing acid rain (Khalid, 2001). Howard et al. (2013, p. 51) noted that college students have "several naive conceptions related to chemistry and greenhouse gases" that prevent them from correctly conceptualizing the related scientific processes and phenomena. These misconceptions could be useful as teaching tools to better anticipate and support students' in modifying their ideas about ocean acidification, carbon dioxide, and climate change.

\section{Of the Three Student Populations, a Greater Proportion of Environmental Studies Students Demonstrated Awareness of Ocean Acidification and Identified Carbon Dioxide as the Cause, Compared with Biology or Chemistry/Biochemistry Students}

Environmental studies students' responses to multiple assessment items more closely resembled faculty responses than biology and chemistry/biochemistry students. More environmental studies students listed ocean acidification as an impact of climate change, unprompted, compared with biology students and chemistry/biochemistry students (Figures 1E and 2B). Additionally, more environmental studies students disagreed with the statement "The main impact greenhouse gases have on the ocean is they increase the ocean's temperature," compared with biology or chemistry students (Figure 2A). A greater proportion of environmental studies students also reported they had heard of ocean acidification and used carbon dioxide to explain the cause of ocean acidification (Figure 4, A and B).

What might be responsible for these differences among undergraduate science student populations? One potential origin of the differences among students in the three disciplines may be that course content encountered by environmental studies students is most directly related to the topics of the environment and climate change. Alternatively, a second potential origin of these differences may be that environmental studies courses are taught in a fundamentally different way than biology and chemistry/biochemistry courses. Environmental studies curriculum and/or pedagogical approaches may be more interdisciplinary, providing students with opportunities within course work to see connections among topics and to integrate concepts from life and social sciences, economics, and humanities. As a result, differences in environmental studies awareness and understanding of ocean acidification could possibly have origins in these students having more practice in seeing connections among topics and in transferring conceptual knowledge into a wider context. Third, differences among these student populations could arise from differences in fundamental interest in climate change issues or different levels of motivation in accessing information from other sources, such as the media. Perhaps students who are predisposed to be interested in ocean acidification and other environmental issues are more likely to choose environmental studies as their major or to learn about such topics from nonschool sources. Future studies are needed to investigate the multiple potential origins- curricular, pedagogical, media based, and/or interest based-that could be driving the differences we observed among these three different science major student populations.

\section{Limitations, Future Directions, and Conclusions}

Because this study represents only the conceptions of science students and faculty from one institution, future studies should explore a broader range of disciplines and contexts, such as comparing undergraduate science students' conceptions with those of non-science majors and the general public. It should also be noted that this study was conducted at a university that was within $5 \mathrm{mi}$ of the Pacific Ocean. This proximity might have had an influence, and we would be interested in comparing our results with those of a university located in a landlocked state. 
While the differences among the three different student populations are intriguing, future studies are needed to investigate the origins of these differences. Additionally, a detailed analysis of the different sources of students' understanding of ocean acidification and climate change, such as course work, social networks, family and friends, and news media, might reveal the perceived value of these sources in shaping their conceptions. It was not within the scope of this study to determine whether students were accessing conceptions gained outside their undergraduate science curriculum to answer the assessment questions. Follow-up, videotaped interviews with students who complete the written assessment in future studies could reveal the source or sources of students' ideas on ocean acidification.

Misconceptions uncovered in this study may be a key teaching tool for those seeking to improve climate change education, as these misconceptions could allow instructors to better anticipate how some students may conceptualize ocean acidification. We predict that efforts to explicitly probe misconceptions about the cause of ocean acidification may reveal that undergraduate non-science majors, K-12 students and teachers, and the general public also conflate the topics of acid rain and chemical pollution with ocean acidification. Future investigations could aid scientists and instructors in better understanding the barriers to achieving a scientifically accurate understanding of climate change and ocean acidification for all these populations.

To our knowledge, this is the first study that has investigated undergraduate science students' conceptions and misconceptions of ocean acidification. Our results revealed that students and faculty are in agreement that undergraduate science students should understand climate change. Students in this study also demonstrated that they have some of the context-specific scientific knowledge necessary to understand ocean acidification. But not all students appear to apply this knowledge in the context of their explanations of ocean acidification. In conclusion, if the advanced undergraduate science students studied here do not emerge from their disciplinary training able to understand ocean acidification, who will?

\section{ACKNOWLEDGMENTS}

We thank the undergraduate students and the faculty who participated in this study. We thank all the members of the SEPAL lab, as well as Drs. Meg Burke and Anne Todgham, for helpful comments on early drafts of this article. We also thank our editors and reviewers at CBE-Life Sciences Education for their constructive feedback, which strengthened this article. K.I.D. was supported by a National Science Foundation Graduate Research Fellowship for Biology Education Research (DGE-0948369). K.D.T. was supported by a National Science Foundation CAREER grant (DRL-0954127).

\section{REFERENCES}

Andersson AJ, Mackenzie FT (2011). Ocean acidification: setting the record straight. Biogeosci Discuss 8, 6161-6190.

Andersson B, Wallin A (2000). Students' understanding of the greenhouse effect, the societal consequences of reducing $\mathrm{CO}_{2}$ emissions and the problem of ozone layer depletion. J Res Sci Teach 37, 1096-1111.

Boyes E, Stanisstreet M (1992). Students' perceptions of global warming. Int J Environ Stud 42, 287-230.
Doney SC, Fabry VJ, Feely RA, Kleypas JA (2009). Ocean acidification: the other $\mathrm{CO}_{2}$ problem. Annu Rev Mar Sci 1, 169-192.

Dove J (1996). Student teacher understanding of the greenhouse effect, ozone layer depletion and acid rain. Environ Educ Res 1, 89-98.

Fabry VJ, Seibel BA, Feely RA, Orr JC (2008). Impacts of ocean acidification on marine fauna and ecosystem processes. ICES J Mar Sci 65, 414-432.

Fauville G, Saljo R, Dupont S (2012). Impact of ocean acidification on marine ecosystems: educational challenges and innovations. Mar Biol 160, 1863-1874.

Harley CDG, Hughes AR, Hultgren KM, Miner BG, Sorte CJB, Thornber CS, Rodriguez LF, Tomanek L, Williams SL (2006). The impacts of climate change in coastal marine systems. Ecol Lett 9, 228-241.

Hartley LM, Wilke BJ, Schramm JW, D'Avanzo C, Anderson CW (2011). College students' understanding of the carbon cycle: contrasting principle-based and informal reasoning. BioScience 61, 65-75.

Howard KE, Brown SA, Chung SH, Jobson BT, Vanreken TM (2013). College students' understanding of atmospheric ozone formation. Chem Educ Res Prac 14, 51-61.

Khalid T (2001). Pre-service teachers' misconceptions regarding three environmental issues. Can J Environ Educ 6, 102-120.

Kroeker KJ, Kordas RL, Crim R, Hendriks IE, Ramajo L, Singh GS, Duarte CM, Gattuso JP (2013). Impacts of ocean acidification on marine organisms: quantifying sensitivities and interaction with warming. Global Change Biol 19, 1884-1896.

Lambert JL, Lindgren J, Bleicher R (2012). Assessing elementary science methods students' understanding about global climate change. Int J Sci Educ 34, 1167-1187.

Logan CA (2010). A review of ocean acidification and America's response. BioScience 60, 819-828.

Lombardi D, Sinatra GM (2012). College students' perceptions about the plausibility of human-induced climate change. Res Sci Educ 42, 201-217.

National Geographic Society, National Oceanic and Atmospheric Administration, Centers for Ocean Sciences Education Excellence, National Marine Educators Association, College of Exploration (2005). Ocean Literacy: The Essential Principles of Ocean Sciences K-12. http:// oceanservice.noaa.gov/education/literacy/ocean_literacy.pdf.

Ocean Project (2012). Public Awareness of Ocean Acidification, Summer 2012 Report. www.TheOceanProject.org (accessed October 2012).

Orr JC, Fabry VJ, Aumont O, Bopp L, Doney SC, Feely RA, Gnanadesikan A, Gruber N, Ishida A, Joos F, Key RM, et al. (2005). Anthropogenic ocean acidification over the twenty-first century and its impact on calcifying organisms. Nature 437, 681-686.

Parmesan C (2006). Ecological and evolutionary responses to recent climate change. Annu Rev Ecol Evol Syst 37, 637-669.

Sabine CL, Feely RA, Gruber N, Key RM, Lee K, Bullister JL, Wanninkhof R, Wong CS, Wallace DWR, Tilbrook B, et al. (2004). The oceanic sink for anthropogenic $\mathrm{CO}_{2}$. Science 305, 367-371.

Shepardson DP, Niyogi D, Choi S, Charusombat U (2011). Students' conceptions about the greenhouse effect, global warming, and climate change. Climatic Change 104, 481-507.

Shepardson DP, Niyogi D, Roychoudhury A, Hirsch A (2012). Conceptualizing climate change in the context of a climate system: implications for climate and environmental education. Environ Educ Res 18, 323-352.

U.S. Global Change Research Program (2009). Climate Literacy: The Essential Principles of Climate Science, Washington, DC.

Wilson CD, Anderson CW, Heidemann M, Merrill JE, Merritt BW, Richmond G, Sibley DF, Parker JM (2006). Assessing students' ability to trace matter in dynamic systems in cell biology. Cell Biol Educ 5, 323-331. 